\title{
Subdural Hematomun Nadir Bir Nedeni: Enfektif Endokarditi Olan Çocukta Çoklu Septik Beyin Embolisi
}

\author{
A Rare Cause of Subdural Hematoma: Multiple Septic Brain Embolisms in A Child With Infec- \\ tive Endocarditis
}

Gül YUCEL

Konya Training and Research Hospital, Department of Pediatric Neurology, Konya, Turkey.

\begin{abstract}
Özet
Enfektif endokardit (IE) olan hastaların \%25-70'inde serebrovasküler komplikasyonlar ortaya çıar. Bu komplikasyonlar arasında; iskemik inme, intraserebral kanama ve serebral apse sıklıkla görülür ve genellikle vejetasyonun embolizasyonu veya enfeksiyöz (mikotik) anevrizmanın rüptürü sonucu meydana gelir. Akut subdural hematom (ASDH), İE’nin çoklu septik beyin embolisine bağlı çok nadir bir komplikasyonudur. Burada oldukça nadir görülen mikotik anevrizmanın rüptüre olmasından kaynaklanan ASDH vakası olan 15 yaşında bir çocuk sunuldu. Bildiğimiz kadarıyla literatürde İE bağlı ASDH gelişen sadece 13 vaka bildirilmiștir. Burada bildirilen vaka mikotik anevrizma ilișkili-ASDH ve intraserebral kanama olan ikinci çocuk olgudur. Ayrıca mevcut bilgiler dahilinde İE in bu nadir nörolojik komplikasyonunun patogenezi, klinik görünümü ve tedavisi de tartışıldı. Bu çalışmanın amacı, enfektif endokarditli çocuk hastalarda subdural hematomun klinik özelliklerini ve yönetimini literatür ışı̆̆ında incelemektir.
\end{abstract}

Anahtar Kelimeler: Enfektif endokardit, Septik beyin emboli, Subdural hematom, Staphylococcus aeureus

\begin{abstract}
Cerebrovascular complications occur in $25 \%-70 \%$ of patients with infective endocarditis (IE). Among these complications, ischemic stroke, intracerebral hemorrhage and cerebral abscess are frequently seen and usually the consequence of vegetation embolization or ruptured infectious (mycotic) aneurysm. Acute subdural hematoma (ASDH) is a very rare complication of IE due to multiple septic brain embolisms. Presented herein was a 15-year-old child with a very rare presentation of ASDH, which resulted from ruptured mycotic aneurysm. To the best of our knowledge, only 13 cases have been reported in the literature with an ASDH due to IE. The reported case herein was the second child case with mycotic aneurysms- related ASDH and intracerebral hemorrhage. Also discussed were the pathogenesis, clinical manifestation, and management of this rare neurologic complication of IE in the current knowledge. The aim of this study was to analyze the clinical features and management of subdural hematoma in pediatric patients with infective endocarditis in light of the literature.
\end{abstract}

Keywords: Infective endocarditis, Septic brain embolism, Subdural hematoma, Staphylococcus aureus

Yazışma Adresi: Gül YUCEL, Konya Training and Research Hospital, Department of Pediatric Neurology, Konya, Turkey Telefon: 905530305525 Mail: drgulyucel@hotmail.com

ORCID No: 0000-0001-5753-9048

Geliş Tarihi: 10.11 .2020

Kabul Tarihi: 04.01.2021

DOI: $10.17517 /$ ksutfd. 824244 


\section{INTRODUCTION}

Cerebrovascular complications of infective endocarditis (IE) are a prevalent adversity associated with increased morbidity and mortality. The clinical spectrum of these complications includes ischemic stroke in $50 \%-87.2 \%$ of patients, intracerebral hemorrhage in $25.6 \%-69.2 \%$, cerebral abscess in $1 \%-12.8 \%$, meningitis in $1 \%-20 \%$ and aneurysm in $2 \%-8 \%(1-4)$. Neurological events in IE are mainly a consequence of embolism, which is related to the migration of cardiac vegetation. The most common sites of embolism are the brain and spleen in left-sided IE, while lung embolism is common in right-sided and pacemaker lead IE $(5,6)$.

Embolic events may be the first symptom of IE or it may be completely silent. Intracranial mycotic aneurysms (MAs), also known as septic aneurysms, occur in $2 \%-4 \%$ of patients with IE, and in $5 \%-12 \%$ of patients with IE and neurologic complications (1). Magnetic resonance imaging (MRI) of the brain should be performed to detect ischemic and hemorrhagic lesions in any case where a patient has IE with neurological complications (5). Due to the sparsity of these lesions, there has been no consensus about the issue of standard management protocol. Rupture of an MA usually occurs in the acute phase of IE, and it may sometimes occur during or even after the end of antibiotic therapy. MA-related acute subdural hematoma $(\mathrm{ASDH})$ is a very rare occurrence and to date, and only 13 cases have been reported.

Presented here in was the case of 15-year-old child with a rapidly developing $\mathrm{ASDH}$ associated with MA, which led to a fatal evolution.

\section{CASE PRESENTATION}

A 15-year-old child was admitted to the department of Pediatric Neurology Clinic, Konya Training and Research Hospital with an inability to walk, stiff neck, confusion, and left-central facial paralysis. The patient had no history of head trauma, hypertension, or coagulopathy. At 7 days prior to admission to the hospital, headaches, fever, abdominal pain, vomiting, and diarrhea began to occur. On admission, the patient presented with a temperature of $38.8{ }^{\circ} \mathrm{C}$, heart rate of 97 beats/min, respiratory rate of 27 breaths/min, oxygen saturation without oxygen of $91 \%$, and blood pressure of $118 / 56 \mathrm{~mm} / \mathrm{Hg}$.

The physical examination was significant, with the presentation of confusion and a dehydrated appearance. The patient had arthritis in both ankles, Janeway lesions on the base of the thumbs and little fingers, and Osler's nodes on the left thumb and both soles. A grade 2/6 systolic heart murmur was observed, which was loudest in the aortic valve. There was tenderness in the left lower quadrant of the abdomen and hepatosplenomegaly was present. Neurological examination was remarkable with confused consciousness, dysarthric speech, and left central facial paralysis. The pupils of the child were isochoric and reactive to light. The fundus examination revealed grade 1 papilledema with evident optic disc border. Bilateral Roth spots were observed. The patient could not stand without assistance. Motor power was diminished by $4 / 5$ in both lower extremities and deep tendon reflexes were hypoactive, bilaterally. There was no pathological reflex. Stiff neck and meningeal irritation signs (Kernig and Brudzinski) were positive.

In the laboratory examinations, the white blood cell count was $21,700 / \mathrm{mm} 3$ ( $80 \%$ neutrophils), hemoglobin count was $10.1 \mathrm{~g} / \mathrm{dL}$, hematocrit count was $30.2 \%$, platelet count was $146,000 / \mathrm{mm} 3$, C-reactive protein (CRP) count was $94.1 \mathrm{mg} /$ $\mathrm{dL}$, and erythrocyte sedimentation rate was $38 \mathrm{~mm} / \mathrm{h}$. Results of the other laboratory tests were within normal range limits.

Cerebrospinal fluid (CSF) analysis showed a leukocyte count of $455 / \mathrm{mm} 3$ (64\% neutrophils, 36\% lymphocyte), protein count of $221 \mathrm{mg} / \mathrm{dL}$, glucose count of $62 \mathrm{mg} / \mathrm{dL}$ (synchronous measured glucose count of $88 \mathrm{mg} / \mathrm{dL}$ ), and increased CSF pressure. CSF and sequential blood cultures were positive for methicillin-sensitive Staphylococcus aureus (MSSA).

Transthoracic echocardiography (TTE) revealed a severe aortic regurgitation, left ventricle dilatation, and a vegetation of $7 \times 5-\mathrm{mm}$ in diameter on the left ventricular surface of the aortic valve. The patient was diagnosed with IE as a result of the current physical examination and TTE findings.

Ultrasound of the abdomen showed infarction in both kidneys and spleen, in addition to hepatosplenomegaly. The MRI of the abdomen was performed and revealed wedge-shaped heterogenous areas (the largest was $70 \times 25 \mathrm{~mm}$ ), which were suggestive of splenic infarction in the upper pol posterior section of spleen. Moreover, heterogenous areas were observed in both kidneys, and were more prominent on the left side.

The brain MRI demonstrated numerous millimeter size lesion foci with a hyperintense signal intensity and restricted diffusion on the T2A and FLAIR images in the subcortical location of the fronto-parieto-occipital area on vertical level. This signal change was not seen on the T1A images (Figures 1A-1D).

In addition, axial sections through the posterior fossa on the T2A and FLAIR images showed lesions similar to the hyperintense signal intensity on the bilateral cerebellar hemispheres (Figures 2A-2C). No evidence of intracranial aneurysm was detected on the magnetic resonance angiography (MRA).

The patient was hospitalized with the diagnosis of IE and multiple septic brain embolisms. Antibiotic treatment using doxycycline, gentamicin, and vancomycin was initiated. Cerebral angiography was planned with an interventional neuroradiologist, but the general condition of the patient did not allow this to be performed. At $8 \mathrm{~h}$ after hospitalization, the general condition of the patient deteriorated and he lost consciousness. Sudden right hemiparesis developed. The pupils were unisochoric and unreactive to light. The patient was intubated and connected to the respirator. Brain computed 

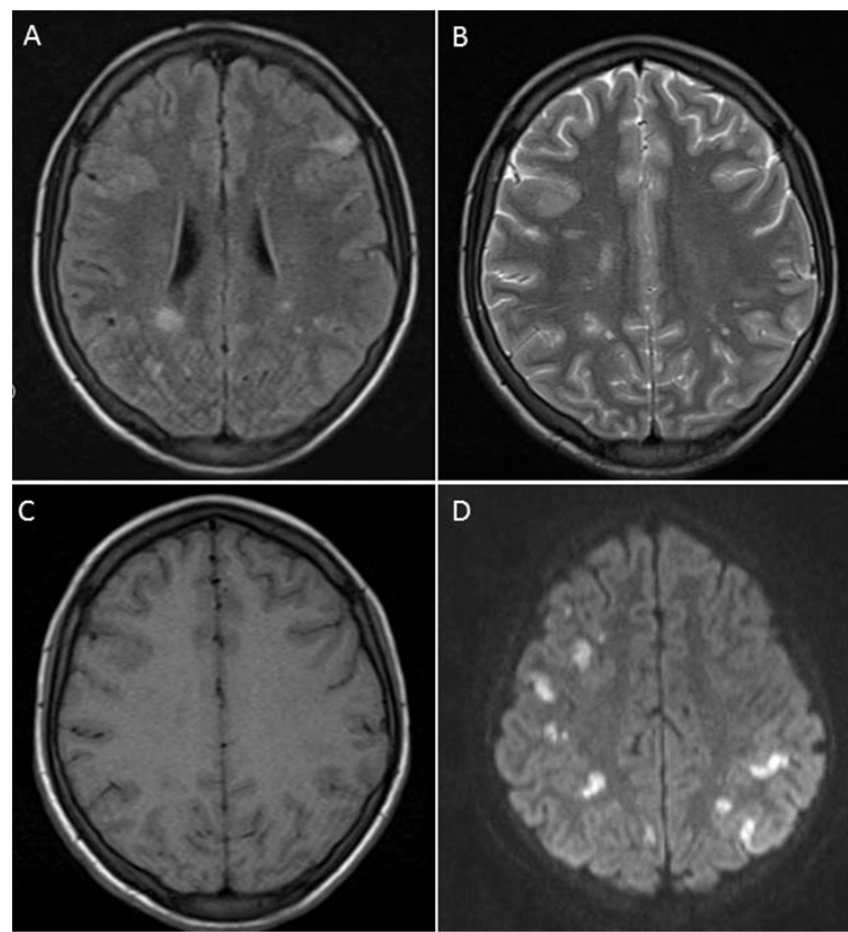

Figure 1. Axial MRI on FLAIR (A) and T2A (B) images demonstrates numerous milimeter size lesion foci with a hyperintense signal intensity. No signal change was on T1A images (C). Diffusion weighted imaging (DWI) (D) shows restricted diffusion with high signal.

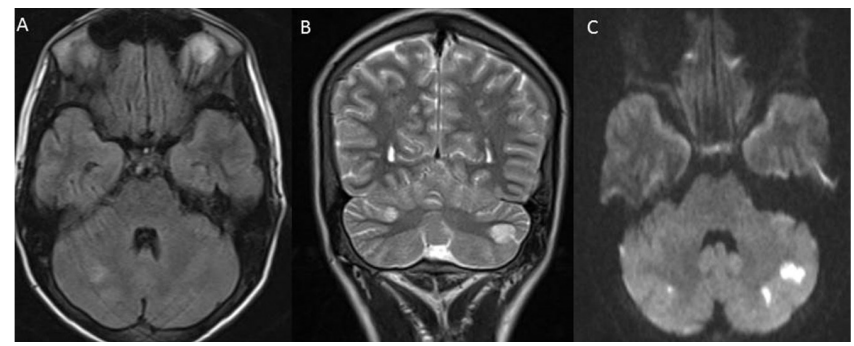

Figure 2. MRI sections through the posterior fossa on FLAIR (A), T2A (B) and DWI (C) imaging shows similar lesions with hyperintense signal intensity with restricted diffusion on the bilateral cerebellar hemispheres.

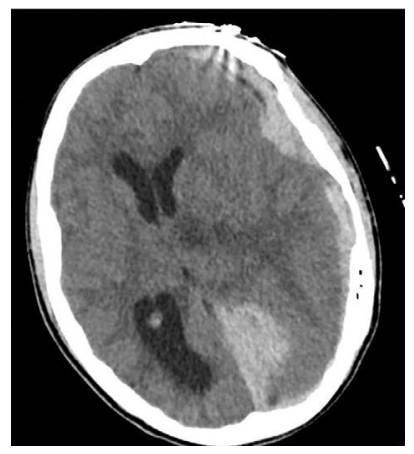

Figure 3. Preoperative, non - contrast - enchanged computerized tomography scan showing acute subdural hematoma localized in supratentorial area and covering the left hemisphere with midline shift, brain edema and also left paramedian occipital hemorrhage. In addition, the hypodens apperance in the posterior part of the intenal capsule, thalamus and basal ganglia suggests subacute ischemia. tomography (CT) was performed after the general condition of the patient worsened. On CT images, an ASDH with a thickness of $1.5 \mathrm{~cm}$ was observed that was localized in the supratentorial area and covered the left hemisphere. Additionally, hypodense lesions were observed in the left hemisphere, which caused a shift in the middle line to the right, due to the limited mass effect in the deep gray matter (brain edema) and also left paramedian occipital hemorrhage (Figure 3).

Despite aggressive neuro-intensive care and antiedema therapy, the brain edema progressed and resulted in transtentorial herniation and midbrain compression. An emergent craniotomy was performed and the subdural hematoma was removed. On the second day postoperatively, the patient died. No autopsy was performed, as the family did not give consent.

\section{DISCUSSION}

MAs, also known as septic aneurysms, account for approximately $2.5 \%-4.5 \%$ of all intracerebral aneurysms and $65 \%$ of patients with MAs have underlying IE with consequent septic embolization (4,7-10). Although the MAs may be caused by bacterial, fungal, or viral microorganisms, they most often result from bacterial infections, most commonly Streptococcus viridans and Staphylococcus aureus $(8,9)$. Ducruet at al. (9) reported a comprehensive review of the existing literature on intracranial MAs. They demonstrated that the median age of MAs was 35.1 years and approximately $52 \%$ of patients were male and $48 \%$ female. Ruptured MAs can manifest as intracerebral (28\%), subarachnoid (22\%), and ventricular (5\%) hemorrhages (9). ASDH is a very rare complication of IE and the incidence of MAs related ASDH ranged between $1.8 \%$ and $3.7 \%$ in the literature $(4,8,9)$. These aneurysms and the associated neurologic complications may be the first symptom of IE.

Infection of the cerebral artery walls, which leads to the formation of MAs, occurs as a result of the hematogenous spread of the existing cardiac vegetation. Erosion of the arterial wall due to septic emboli results in hemorrhages $(6,9)$. The pathogeneses of MA-related ASDH may clarify 2 main mechanisms. First, the small hemorrhages may result in the formation of adhesions with the arachnoid membrane and blood rapidly streaming from the leaking aneurysm may be directly thrown into the subdural space. The second explanatory mechanism is that the blood rapidly streaming out of the leaking aneurysm may rupture the arachnoid membrane by forcing its way into the subdural space $(8,11)$.

To the best of our knowledge, only 13 cases have been reported in the literature with an ASDH due to IE. While only 3 of these cases were pure ASDH $(8,12)$, the others had additional intracerebral and/or subarachnoid hemorrhages $(6,7,11,13-19)$. Of the 8 cases where a valve lesion was specified, the mitral valve was involved in 7 cases $(7,11-$ $14,16,18,19)$, the aortic valve in 1 case $(6,8)$ and the association of both in 3 cases $(8,15,17)$. Almost all of the reported cases were in adults, with the exception of a 13-year-old with 
ASDH and intracerebral hemorrhage, as reported by Kasuya et al. (16). Although, Piastra et al. (10) reported intracerebral and subdural hematoma related with MAs in a 2-month-old baby; however, they did not observe any signs of IE. The reported case herein was the second child case with ASDH and intracerebral hemorrhage.

The clinical presentations of these cases were very variable, including headaches (30\%), fever (28\%), nausea/vomiting (9\%), hemiparesis $(15 \%)$, aphasia (3\%) seizures $(7 \%)$, or loss of consciousness (7\%) (9). Suspicion of MAs should be sufficient for timely diagnosis in such patients with or without endocarditis. A careful history of trauma, drug addiction, previous valvular heart disease, or prosthetic valve history, and a complete physical examination, are mandatory. Given the lack of population-based studies for rigorous comparison, the clinic of these patients deteriorates very rapidly with the rupture of MAs.

During IE, brain MRI frequently detects whether vegetations as small as $4 \mathrm{~mm}$ are related with cerebral embolic lesions, as it gives greater detail regarding parenchymal changes associated with MA (9). However, the identification of MAs is based on the documentation of an intracranial aneurysm by vascular imaging in a patient suspected of having an IE is critical. Thus, a better clinical-radiological correlation can be achieved. Computed tomography angiography (CTA) and MRA can determine aneurysms larger than $5 \mathrm{~mm}$ with reliably. The sensitivity of CTA and MRA for the detection of aneurysms larger than $5 \mathrm{~mm}$ in diameter was $94 \%$ and $86 \%$, respectively, and for the detection of aneurysms smaller than $5 \mathrm{~mm}$ in diameter, it was only $57 \%$ and $35 \%$, respectively (1). CTA and/or MRA may not detect the presence MAs because of mass effect. In this instance, conventional angiography should be performed to identify smaller aneurysms. Conventional angiography is the gold standard due to their distal location within the cerebral arteries $(1,9)$. In the case discussed herein, MRI showed evidence of acute multiple septic brain embolisms without hemorrhage and MRA did not detect any evidence of intracranial aneurysm. Conventional angiography was planned, but could not be performed, as the condition of the patient deteriorated rapidly within an approximate 8-h period. Therefore, it was not possible to exclude or confirm that the ASDH was due to MAs. This seemed to be the most likely pathogenic mechanism with the current data.

In addition to imaging, positive cultures from cerebrospinal fluid and/or blood can confirm the diagnosis of MAs and help in deciding which antibiotic therapy to initiate. However, only $35.6 \%$ of the patients screened in the literature had positive culture (9). In the current case, MSSA was positive in the CSF and blood cultures.

Based on the results of the literature, the management of MA remains controversial. Treatment approaches involve a combination of antibiotic therapy, surgical, and/or endovascular approaches. Antibiotic therapy is the only treatment option that has proven itself, and may reduce embolic in- cidence. Antibiotic therapy should be started immediately empirical, and then modified according to culture results $(1,9,17)$. In combination with prompt antibiotic therapy, resolution requires confirmation by a serial angiography beginning at 1-2 weeks following the initiation of therapy (9). If the size of the MA has decreased or resolved, then a surgical or endovascular approach is usually redundant. Given the high rate of rupture of MAs, if the aneurysm size increases or remains unvaried, aneurysms with favorable morphology and location may be treated with surgical or endovascular treatment $(9,20)$. Barami et al. (17) suggested that the treatment of patients with MA-related ASDH consists of the discharge of the hematoma and then excision of the aneurysm. Afterwards, at least 6 weeks of intravenous antibiotic therapy and appropriate angiographic follow-up should be performed (17). There is no certain evidence on the routine use of antiplatelet or anticoagulant drugs in patients with potential neurological complications of IE $(1,3,9)$.

Given the infrequency of MA-related ASDH in a child, the most considerable lesson to be learned is that early diagnosis and rigorous individualized treatment is crucial to the accomplished management. Conventional angiography is considered the gold standard imaging modality for the evaluation of MAs. The baseline therapy should be an antibiotic therapy.

\section{Consent:}

Written informed consent was obtained from the family for publication of this case report and any concomitant images.

\section{Declaration of conflicting interests:}

The authors declared no conflicts of interest with respect to the authorship and/or publication of this article.

\section{Funding:}

The authors received no financial support for the research and/or authorship of this article.

\section{REFERENCES}

1. Silver B, Behrouz R, Silliman S. Bacterial Endocarditis and Cerebrovascular Disease. Curr Neurol Neurosci Rep 2016; 16:104.

2. Novy E, Sonneville R, Mazighi M, Klein IF, Mariotte E, Mourvillier B,et al. Neurological complications of infective endocarditis: new breakthroughs in diagnosis and management. Med Mal Infect 2013; 43: 443-450.

3. Pruitt AA. Neurologic complications of infective endocarditis. Curr Treat Options Neurol 2013; 15: 465-476.

4. Duval X, Iung B, Klein I, Brochet E, Thabut G, Arnoult F,et al. Effect of early cerebral magnetic resonance imaging on clinical decisions in infective endocarditis: a prospective study. Ann Intern Med 2010; 152: 497-504.

5. Habib G, Hoen B, Tornos P, Thuny F, Prendergast B, Vilacosta I, et al. Guidelines on the prevention, diagnosis, and treatment of infective endocarditis (new version 2009): the Task Force on the Prevention, Diagnosis, and Treatment of Infective Endocarditis of the European Society of Cardiology (ESC). Endorsed by the European Society 
of Clinical Microbiology and Infectious Diseases (ESCMID) and the International Society of Chemotherapy (ISC) for Infection and Cancer.

6. Geisenberger D, Huppertz LM, Büchsel M, Kramer L, Pollak S, GroßePerdekamp M. Non-traumatic subdural hematoma secondary to septic brain embolism: A rare cause of unexpected death in a drug addict suffering from undiagnosed bacterial endocarditis. Forensic Sci Int 2015; 257: 1-5.

7. Yamakawa H, Hattori T, Tanigawara T, Enomoto Y, Ohkuma A. Ruptured infectious aneurysm of the distal middle cerebral artery manifesting as intracerebral hemorrhage and acute subdural hematoma--case report. Neurol Med Chir 2003; 43: 541-545.

8. Boukobza M, Duval X, Laissy JP. Mycotic intracranial aneurysms rupture presenting as pure acute subdural hematoma in infectious endocarditis. Report of 2 cases and review of the literature. J Clin Neurosci 2019; 62: 222-225.

9. Ducruet AF, Hickman ZL, Zacharia BE, Narula R, Grobelny BT, Gorski J, et al. Intracranial infectious aneurysms: a comprehensive review. Neurosurg Rev 2010; 33: $37-$ 46.

10. Piastra M, Chiaretti A, Tortorolo L. Ruptured intracranial mycotic aneurysm presenting as cerebral haemorrhage in an infant: case report and review of the literature. Childs Nerv Syst 2000; 16: 190-193.

11. Bandoh K, Sugimura J, Hosaka Y, Takagi S. Ruptured intracranial mycotic aneurysm associated with acute subdural hematoma--case report. Neurol Med Chir 1987; 27: 56-59.

12. King AB. Successful surgical treatment of an intracranial mycotic aneurysm complicated by a subdural hematoma. J Neurosurg 1960; 17: 788-791.

13. Matsuda T, Kiyosue H, Yamashita M, Tanoue S, Okahara $\mathrm{M}$, Nagatomi $\mathrm{H}$, et al. A case of multiple mycotic intracranial aneurysms presenting with subdural hematoma. Neurological surgery 2002; 30: 73-78.

14. Yanagihara C, Wada Y, Nishimura Y. Infectious endocarditis associated with subarachnoid hemorrhage, subdural hematoma and multiple brain abscesses. Intern Med 2003; 42: 1244-1247.

15. Rasmussen M, Björk Werner J, Dolk M, Christensson B. Lactococcus garvieae endocarditis presenting with subdural haematoma. BMC Cardiovasc Disord 2014; 14: 13.

16. Kasuya H, Shimizu T, Tajika T, Kitamura K, Okada N, Sugama M, et al.A case of septic aneurysm complicated with simultaneous subdural and intracerebral hematoma. Neurological surgery 1985; 13: 1109-1113.

17. Barami K, Ko K. Ruptured mycotic aneurysm presenting as an intraparenchymal hemorrhage and nonadjacent acute subdural hematoma: case report and review of the literature. Surg Neurol 1994; 41: 290-293.

18. Bamford J, Hodges J, Warlow C. Late rupture of a mycotic aneurysm after "cure" of bacterial endocarditis. J Neurol 1986; 233: 51-53.

19. Sugino T, Yamamoto K, Kidooka M, Otsuka S. A ruptured mycotic aneurysm, simultaneously associated with acute subdural hematoma and intracerebral hemorrhage: case report and review of the literatüre. Neurological surgery 2002; 30: 1211-1215.

20. Bartakke S, Kabde U, Muranjan MN, Bavdekar SB. Mycotic aneurysm: an uncommon cause for intra-cranial hemorrhage. Indian J Pediatr 2002; 69: 905-907. 